\title{
HUBUNGAN ANTARA BEBERAPA INDIKATOR STATUS GIZI DENGAN TEKANAN DARAH PADA REMAJA
}

\author{
Eva Novianingsih, Apoina Kartini*) \\ Program Studi Ilmu Gizi Fakultas Kedokteran Universitas Diponegoro \\ Jl.Dr.Sutomo No.14, Semarang, Telp (024) 8453708, Email : gizifk@undip.ac.id
}

\begin{abstract}
Background: Hypertension does not only occurs on adults only, but also on adolescence. In Indonesia hypertension prevalence on adolescence was $8,4 \%$. On obese children there were 20 - 30\% of hypertension prevalence. The objective of the study was to examine which nutritional status indicators have the greatest assosiation with blood pressure on adolescence.

Method: Subjects of this cross sectional study consisted of 34 adolescence aged 11 - 14 year old. Body Mass Index (BMI), Waist Circumference (WC), Waist to Height ratio (WtHR), and Neck Circumference (NC) was determined as independent variables, Sistolic Blood Pressure (SBP) and Diastolic Blood Pressure (DBP) as dependent variables. Pearson Product Moment and Multivariat Linear Backward Regression were used for data analysis.

Result: The prevalence of obesity based on BMI was $14,7 \%$, WC was $23,5 \%$, WtHR was $47,1 \%$, dan NC was $29,5 \%$. The prevalence of hypertension was 14,7\%. Result from bivariat test showed that all indicators were significantly correlate with blood pressure. Result from multivariate test showed that in both genders BMI had the greatest assosiation with SBP and DBP $(\beta, 0.440 ; p, 0.010$ and $\beta, 0.693 ; p, 0.000)$. BMI had the greatest assosiation with $\operatorname{SBP}(\beta, 0.76 ; p, 0.000)$ and $W C$ with $D B P(\beta, 0.708 ; p, 0.001)$ in boys. NC had the greatest assosiation with $S B P$ and $D B P(\beta, 0.871 ; p, 0.000$ dan $\beta, 0.828 ; p, 0.000)$ in girls.

Conclusion: Nutritional status indicators which had the greatest assosiation with blood pressure was BMI and WC in boys, NC in girls, and BMI in both genders.
\end{abstract}

Key word: nutritional status; obesity; blood pressure; adolescence

\begin{abstract}
ABSTRAK
Latar belakang: Hipertensi tidak hanya terjadi pada orang dewasa, tetapi juga dapat terjadi pada remaja. Di Indonesia prevalensi hipertensi remaja sebesar 8,4\%. Pada anak obesitas ditemukan prevalensi hipertensi sebesar 20 - 30\%. Tujuan penelitian ini adalah untuk mengetahui indikator status gizi mana yang paling berpengaruh terhadap tekanan darah pada remaja.

Metode: Rancangan penelitian adalah cross sectional dengan jumlah subyek 34 anak usia 11 - 14 tahun. Indikator status gizi terdiri dari Indeks Masa Tubuh (IMT), Lingkar Pinggang (LiPi), Rasio Lingkar Pinggang Tinggi Badan (RLPTB), dan Lingkar Leher (LL) ditetapkan sebagai variabel independen, sedangkan tekanan darah sistolik (TDS) dan tekanan darah diastolik (TDD) sebagai variabel dependen. Uji statistik yang digunakan adalah pearson product moment dan multivariat linear backward regression.

Hasil: Prevalensi obesitas berdasarkan IMT/U sebesar 14,7\%, LiPi sebesar 23,5\%, RLPTB sebesar 47,1\%, dan LL sebesar 29,5\%. Prevalensi hipertensi sebesar 14,7\%. Hasil uji bivariat menunjukkan bahwa semua variabel mempunyai hubungan signifikan dengan tekanan darah. Hasil uji multivariat menunjukkan bahwa pada kedua jenis kelamin TDS dan TDD dipengaruhi oleh IMT ( $\beta, 0.440 ; p, 0.010$ dan $\beta, 0.693 ; p, 0.000)$. Pada remaja Laki - laki TDS dipengaruhi oleh IMT ( $\beta, 0.76 ; p, 0.000)$ dan TDD oleh LiPi $(\beta, 0.708 ; p, 0.001)$. Pada remaja perempuan TDS dan TDD dipengaruhi oleh $L L$ ( $\beta, 0.871 ; p, 0.000$ dan $\beta, 0.828 ; p, 0.000)$.

Kesimpulan: Indikator status gizi yang paling mempengaruhi tekanan darah pada remaja laki - laki adalah IMT dan LiPi, pada remaja perempuan adalah LL, dan pada kedua jenis kelamin adalah IMT.
\end{abstract}

Kata Kunci: status gizi; obesitas; tekanan darah; remaja

\section{PEDAHULUAN}

Hipertensi disebut juga sebagai pembunuh gelap (the silent kiler) karena karena merupakan penyakit mematikan tanpa gejala telebih dahulu. Hipertensi yang tidak terkontrol dan terdekteksi dapat menyebabkan terjadinya serangan jantung, stroke, dan gagal ginjal. ${ }^{1}$
Hipertensi tidak hanya terjadi pada orang dewasa atau usia lanjut, tetapi juga dapat terjadi pada anak - anak dan remaja. ${ }^{2}$ Hipertensi jarang terjadi pada anak - anak, tetapi prevalensinya meningkat dengan meningkatnya kejadian overweight. $^{3}$ Prevalensi hipertensi remaja di Indonesia sebesar $8,4 \% .^{2}$ Pada anak obesitas

${ }^{*}$ Penulis Penanggungjawab 
ditemukan prevalensi hipertensi sebanyak 20 $30 \%{ }^{4}$ Pada penderita obesitas terjadi peningkatan tekanan darah, hal ini disebabkab oleh beberapa hal antara lain aktifasi Simpathetic Nervous System (SNS), abnormalitas mekanisme diuresis dan natriuresis, aktifasi Rennin-Angiotensin System $(R A S)$, gangguan fungsi ginjal, resistensi insulin, hyperleptinemia, dan vascular endhotelial dysfunction. ${ }^{5}$ Prevalensi Obesitas anak usia sekolah (6 - 14 tahun) di Indonesia adalah 9,5\% (laki laki) dan $6,4 \%$ (Perempuan). ${ }^{2}$

Indikator status gizi yang dikaitkan dengan tekanan darah antara lain Indeks Masa Tubuh (IMT), Lingkar Pinggang (LiPi), Rasio Lingkar Pinggang Terhadap Tinggi Badan (RLPTB), dan Lingkar Leher (LL). ${ }^{6,7}$ IMT mempunyai hubungan yang kuat dengan tekan darah. ${ }^{6}$ IMT $\geq$ persentil $95^{\text {th }}$ berhubungan kuat dengan peningkatan tekanan darah $\geq$ persentil $90^{\text {th }}(\mathrm{RR}, 3.8 ; 95 \% \mathrm{CI} ; 2.6-$ 5.4). ${ }^{8}$ Pada remaja laki - laki dan perempuan dengan IMT $\geq$ persentil $90^{\text {th }}$ mempunyi tekanan darah sistolik tinggi sebesar $35,7 \%$ dan $14,0 \%$, dan tekanan darah diastolik tinggi sebesar $24,7 \%$ dan 15,9\%. ${ }^{9}$ LiPi menggambarkan akumulasi lemak intra-abdominal atau lemak viseral. Bertambahnya ukuran LiPi berkaitan erat dengan peningkatan faktor risiko penyakit kardiovaskuler. ${ }^{10}$ Pada remaja laki - laki dan perempuan dengan LiPi $\geq$ persentil $90^{\text {th }}$ mempunyai tekanan darah sistolik tinggi sebesar 35,9\% dan 9,2\%, dan tekanan darah diastolik tinggi sebesar $21,6 \%$ dan $12,1 \% .{ }^{9}$ RLPTB merupakan indeks antropometri yang paling baik dan sederhana untuk mengidentifikasi risiko penyakit kardio-metabolik pada orang dewasa dan anak normalweight maupun overweight. ${ }^{11,12} \mathrm{LL}$ merupakan indeks antropometri yang dapat digunakan untuk menentukan upper body obesity. Lingkar leher dapat digunakan sebagai skrining sedehana dan cepat untuk mengidentifikasi overweight dan obesitas. Besar lingkar leher berhubungan positif dengan risiko penyakit kardiometabolik. $^{7,13}$

Berdasarkan laporan RISKESDAS 2007 provinsi Bengkulu, prevalensi obesitas pada penduduk usia $>15$ tahun kabupaten Kaur sebesar $6,1 \%$ (laki - laki ) dan 8,3\% (perempuan). ${ }^{14}$ SMP Negeri 1 Kaur Selatan merupakan sekolah favorit dan terletak dipusat kota, selain itu sebagian besar siswa berasal dari keluarga dengan status ekonomi menengah keatas. Penelitian ini dilaksanakan di SMP Negeri 1 Kaur Selatan dengan harapan banyak terdapat siswa yang menderita obesitas. Penelitian ini bertujuan untuk mengetahui indikator status gizi mana yang paling berpengaruh dengan tekanan darah pada remaja.

\section{METODE}

Pengambilan data dilakukan pada bulan Agustus 2012. Penelitian ini termasuk lingkup penelitian gizi masyarakat dan merupakan penelitian analitik cross-sectional. Jumlah sampel sebanyak 34 anak dipilih secara proportional random sampling dari murid kelas VII, VIII, dan IX. Sampel yang terpilih bersedia mengikuti penelitian dan hadir pada waktu pengambilan data.

Variabel bebas (independen) dalam penelitian adalah IMT, LiPi, RLPTB, dan LL, sedangkan variabel terikat (dependen) adalah tekanan darah. Data yang dikumpulkan anatara lain identitas sampel, berat badan (BB),tinggi badan (TB), LiPi, RLPTB, LL, tekanan darah sistolik (TDS), dan tekanan darah sistolik (TDD).

TDS dan TDD diukur dengan menggunakan sphygmomanometer digital. Data akhir yang dipakai adalah rata - rata dua kali pengukuran, kemudian data dikategorikan tidak hipertensi jika TDS dan TDD < persentil $95^{\text {th }}$ dan hipertensi jika TDS dan/atau TDD $\geq$ persentil $95^{\text {th }}$ menurut usia, jenis kelamin, dan tinggi badan dalam The Fourth Report on The Diagnosis, Evaluation, and Treatment of High Blood Pressure in Children and Adolescents tahun 2004. ${ }^{15}$ IMT didefinisikan sebagi indeks yang diperoleh dari pengukuran $\mathrm{BB}$ dengan menggunakan timbangan injak digital (kapasitas $120 \mathrm{~kg}$, ketelitian $0,1 \mathrm{~kg}$ ) dan pengukuran TB dengan menggunakan microtoise (kapasitas $200 \mathrm{~cm}$, ketelitian $0,1 \mathrm{~cm}$ ) yang dihitung menggunakan rumus berat badan (kg) dibagi dengan kuadrat tinggi badan (m). IMT dihitung dengan menggunakan WHO anthroplus, data kemudian dikategorikan tidak obesitas jika $\mathrm{IMT} / \mathrm{U} \leq+2 \mathrm{SD}$ dan obesitas jika IMT $>+2 \mathrm{SD}$ menurut usia dan jenis kelamin. ${ }^{16} \mathrm{LiPi}$ diperoleh melalui hasil pengukuran lingkar tepat dibawah tulang rusuk terendah, data kemudian dikategorikan tidak obesitas jika LiPi $<$ persentil $90^{\text {th }}$ dan obesitas jika $\mathrm{LiPi} \geq$ persentil $90^{\text {th }}$ menurut usia dan jenis kelamin. ${ }^{17,18}$ Nilai RLPTB merupakan hasil perbandingan nilai lingkar pinggang $(\mathrm{cm})$ dan tinggi badan $(\mathrm{cm})$, data kemudian dikategorikan tidak obesitas jika < persentil $90^{\text {th }}$ dan obesitas jika $\geq$ persentil $90^{\text {th }}$ menurut usia dan jenis kelamin. ${ }^{18}$ LL diukur pada posisi berdiri tegak, tenang dan kepala menghadap lurus kedepan, tepat pada kartilago tiroid. Pita ukur tidak menekan leher telalu ketat. Data yang diperoleh dikategorikan tidak obesitas jika $<$ cut- 
off value dan obesitas jika $\geq$ cut-off value berdasarkan usia dan jenis kelamin. ${ }^{19}$ Pengukuran LiPi dan Lingkar leher menggunakan pita ukur (metline) kapasitas $150 \mathrm{~cm}$ dengan ketelitian 0,1 $\mathrm{cm}$.

Analisis data menggunakan program Statistical Package for the Social Science (SPSS). Analisis univariat dilakukan untuk mendeskripsikan masing - masing variabel. Analisis bivariat dilakukan untuk melihat hubungan masing - masing variabel independen dengan variabel dependen menggunakan uji pearson product moment. Analisis multivariat dilakukan untuk mengetahui variabel independen mana yang paling mempengaruhi variabel dependen dengan menggunakan uji multivariate linear backward regression.

\section{HASIL PENELITIAN}

Subyek pada penelitian ini berjumlah 34 orang terdiri dari 52,9\% $(\mathrm{n}=18)$ remaja laki - laki dan $47,1 \%(n=16)$ remaja perempuan. Rata - rata umur remaja laki - laki $(13,3 \pm 0,8)$ lebih tinggi dibandingkan dengan remaja perempuan $(12,2 \pm 1,02)$. Prevalensi hipertensi pada remaja sebesar $14,7 \%$. Terdapat $16,7 \%$ remaja laki - laki dan $12,5 \%$ remaja perempuan mengalami hipertensi. Prevalensi Obesitas berdasarkan RLPTB sebesar $47,1 \%$. Terdapat $44,4 \%$ remaja laki - laki dan $50 \%$ remaja perempuan menderita obesitas. Hasil secara rinci terdapat pada tabel 1 dan 2.

Tabel 1. Karakteristik subyek menurut Umur, BB, TB, IMT, LiPi, RLPTB, LL, TDS, dan TDD berdasarkan jenis kelamin

\begin{tabular}{lcccccc}
\hline \multirow{2}{*}{ Variabel } & \multicolumn{3}{c}{ Laki - laki $(\mathrm{n}=18)$} & \multicolumn{3}{c}{ Perempuan $(\mathrm{n}=16)$} \\
\cline { 2 - 7 } & Min. & Maks. & Mean \pm SD & Min. & Maks & Mean \pm SD \\
\hline Umur (th) & 12 & 14 & $13,3 \pm 0,8$ & 11 & 14 & $12,2 \pm 1,02$ \\
BB (kg) & 34,1 & 72,9 & $52,9 \pm 9,6$ & 29,1 & 66,1 & $45,2 \pm 10,1$ \\
TB $(\mathrm{cm})$ & 139,6 & 166,9 & $154,6 \pm 7,4$ & 122,0 & 159,1 & $146,2 \pm 9,03$ \\
IMT (kg/m $\left.{ }^{2}\right)$ & 17,5 & 28,3 & $22,1 \pm 3,2$ & 15,0 & 27,8 & $21,05 \pm 3,85$ \\
LiPi (cm) & 60,4 & 93,4 & $72,05 \pm 9,1$ & 40,5 & 77,3 & $62,85 \pm 9,6$ \\
RLPTB & 0,39 & 0,58 & $0,46 \pm 0,05$ & 0,29 & 0,60 & $0,43 \pm 0,08$ \\
LL(cm) & 30,0 & 38,1 & $33,1 \pm 2,4$ & 22,5 & 36,3 & $28,9 \pm 3,04$ \\
TDS (mmHg) & 100 & 125 & $112,8 \pm 7,4$ & 93 & 120 & $107,0 \pm 7,8$ \\
TDD (mmHg) & 60 & 85 & $69,4 \pm 7,3$ & 58 & 80 & $69,3 \pm 6,9$ \\
\hline
\end{tabular}

$\mathrm{BB}$, berat badan; TB, tinggi badan; IMT, indeks masa tubuh; LiPi, lingkar pinggang; RLPTB, rasio lingkar pinggang terhadap tinggi badan; LL, lingkar leher; TDS, tekanan darah sistolik; TDD, tekanan darah diastolik.

Tabel 2. Distribusi frekuensi kejadian hipertensi dan obesitas

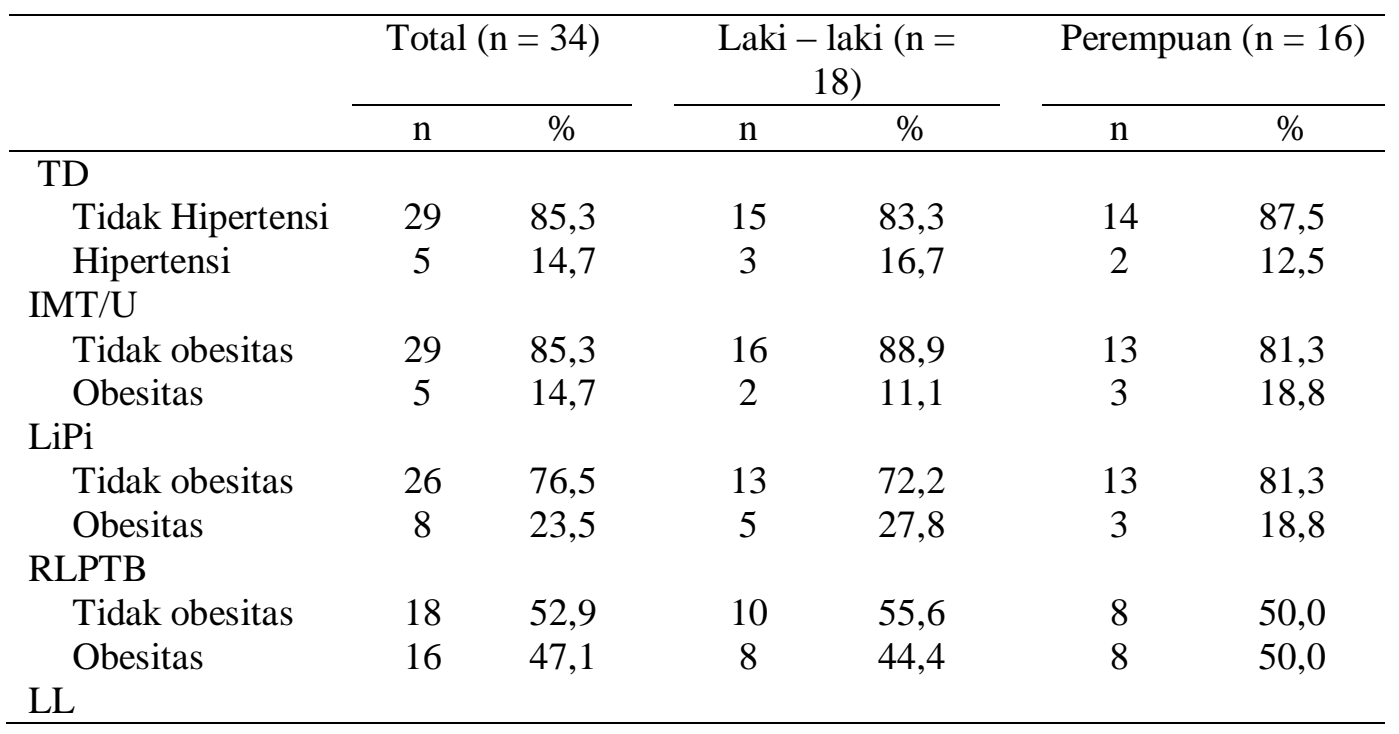




$\begin{array}{lcccccc}\text { Tidak obesitas } & 24 & 70,6 & 11 & 61,1 & 13 & 81,3 \\ \text { Obesitas } & 10 & 29,4 & 7 & 38,9 & 3 & 18,8\end{array}$

TD, tekanan darah; IMT, indeks masa tubuh; LiPi, lingkar pinggang; RLPTB, rasio lingkar pinggang terhadap tinggi badan; LL, lingkar leher.

Hasil analisis bivariat menunjukkan bahwa terdapat hubungan yang signifikan antara indikator status gizi (IMT, LiPi, RLPTB, dan LL) dengan tekanan darah (TDS dan TDD) baik pada remaja laki -laki, perempuan, maupun pada kedua jenis kelamin $(P$ value $<0,05)$. Hasil secara rinci terdapat pada tabel 3 .

Tabel 3. Hasil analisis bivariat Pearson Product Moment antara indikator status gizi dengan tekanan darah

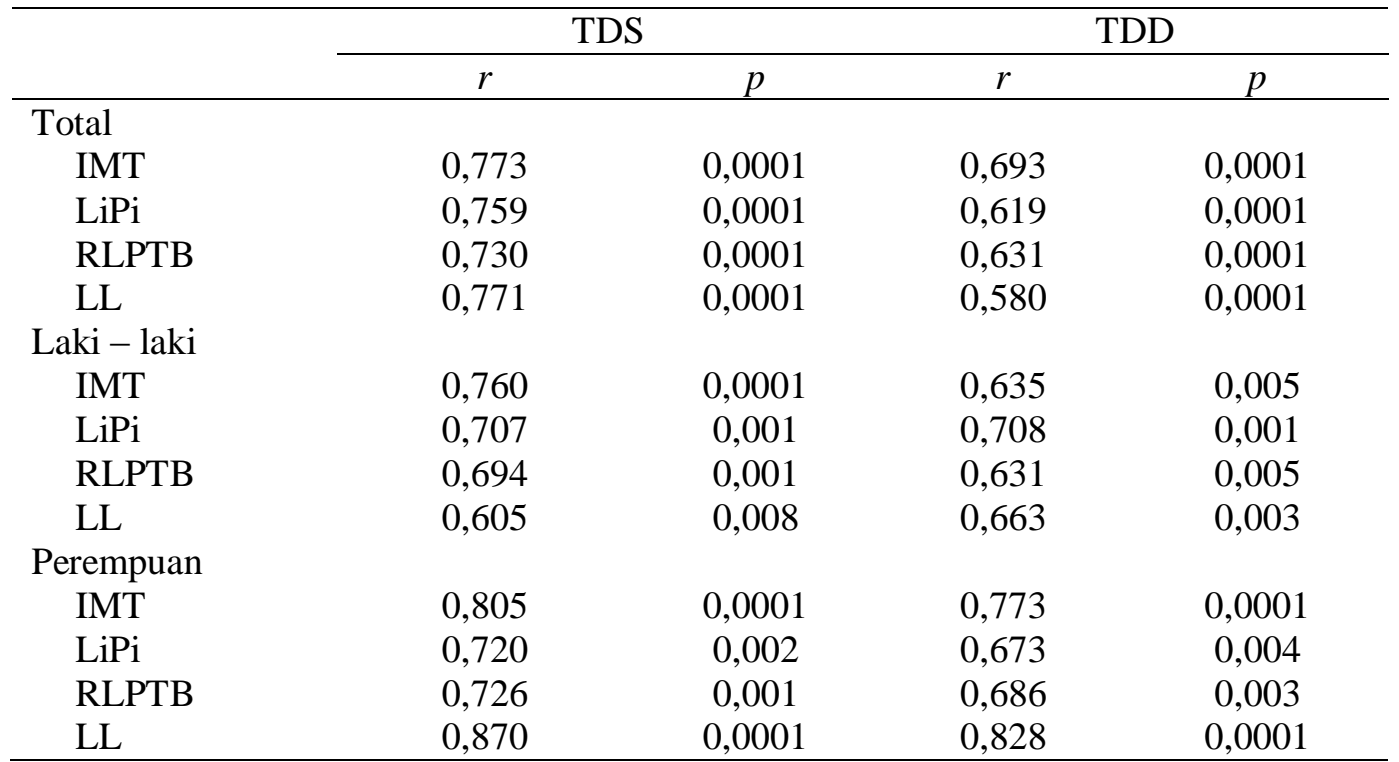

IMT, indeks masa tubuh; LiPi, lingkar pinggang; RLPTB, rasio lingkar pinggang terhadap tinggi badan; LL, lingkar leher; TDS, tekanan darah sistolik; TDD, tekanan darah diastolik.

Berdasarkan analisis multivariate didapatkan hasil pada kedua jenis kelamin indikator yang paling besar pengaruhnya terhadap TDS dan TDD adalah IMT $(\beta, 0.440 ; p, 0.010$ dan $\beta, 0.693 ; p, 0.0001)$. Pada remaja laki - laki, indikator yang paling besar pengaruhnya terdahap TDS adalah IMT $(\beta, 0.760$; $p, 0.0001)$, sedangkan pada TDD adalah LiPi $(\beta$, $0.708 ; p, 0.001)$. Pada remaja perempuan, indikator yang paling besar pengaruhnya terhadap TDS dan TDD adalah LL $(\beta, 0.871 ; p, 0.0001$ dan $\beta, 0.828$; $p, 0.0001)$. Hasil secara rinci terdapat pada tabel 4 dan 5 (lampiran).

\section{PEMBAHASAN}

Pada penelitian ini ditemukan prevalensi hipertensi sebesar 14,7\% dengan TDS dan/ TDD $\geq$ persentil $95^{\text {th }}$. Hasil ini menunjukkan bahwa hipertensi pada tempat penelitian juga sudah terjadi pada remaja. Prevalensi ini lebih tinggi dibandingkan dengan prevalensi hipertensi remaja berdasarkan RISKESDAS 2007 yaitu sebesar $8,4 \% .^{2}$ Penelitian di beberapa negara menunjukkan bahwa prevalensi hipertensi remaja cenderung meningkat. ${ }^{9,18,20}$ Penelitian tahun 2008 di Kab. Semarang dengan subyek berusia $8-12$ tahun terdapat prevalensi hipertensi sebesar $18 \% .^{21}$ Sedangkan pada penelitian tahun 2009 di kota Semarang dengan subyek berusia $11-14$ tahun terdapat prevalensi hipertensi $33,3 \%{ }^{22}$

Pada penelitian ini ditemukan hubungan signifikan antara IMT dengan TDS dan TDD baik pada remaja laki - laki, perempuan, maupun kedua jenis kelamin $(p<0,05)$. Setelah dilakukan analisis multivariat didapatkan hasil bahwa IMT merupakan indikator yang paling mempengaruhi TDS dan TDD pada kedua jenis kelamin $(p, 0.01$ dan $p, 0.0001)$, dan TDS pada remaja laki - laki ( $p$, 0.0001). Hasil ini sesuai dengan penelitian di Iran yang menyatakan bahwa IMT merupakan indikator yang paling sesuai untuk memprediksi dislipidemia 
dan tekanan darah tinggi pada anak dan remaja. ${ }^{23}$ Penelitian Cao et al di China tahun 2009 dengan subyek berusia 12 - 17 tahun menyatakan bahwa IMT berkaitan erat dengan TDS (OR, 14.2; 95\% CI; 12.4 - 16.2 dan OR, 19.4; 95\% CI; 15.2 - 24.7) dan TDD (OR, 6.2; 95\% CI; 5.3 - 7.2 dan OR, 11.8; 95\% CI; 9.0 - 15.5) pada remaja laki - laki dan perempuan. ${ }^{24}$ Pada orang dewasa IMT juga merupakan indikator yang mempunyai hubungan paling kuat dengan TDS dan TDD pada kedua jenis kelamin. ${ }^{6}$

Pada penelitian ini ditemukan hubungan signifikan antara LiPi dengan TDS dan TDD baik pada remaja laki - laki, perempuan, maupun kedua jenis kelamin $(p<0,05)$. Setelah dilakukan analisis multivariat didapatkan hasil bahwa LiPi merupakan indikator yang paling mempengaruhi TDD pada remaja laki - laki $(p, 0.001)$. Hasil ini sesuai dengan penelitian Choy et al yang menyatakan bahwa LiPi mempunai hubungan yang signifikan dengan TDS dan TDD pada anak laki laki dan perempuan. Lipi merupakan indikator yang paling mempengaruhi kenaikan tekanan darah pada anak (OR, 6.03; 95\% CI; $3.59-10.1){ }^{25}$

Pada penelitian ini ditemukan hubungan signifikan antara RLPTB dengan TDS dan TDD baik pada remaja laki - laki, perempuan, maupun kedua jenis kelamin $(p<0,05)$. Setelah dilakukan analisis multivariat didapatkan hasil bahwa bukan merupakan faktor yang mempengaruhi TDS dan TDD. Hasil ini sesuai dengan hasil penelitian di Iran yang menyatakan bahwa IMT, LiPi, dan RLPTB mempunyai hubungan signifikan dengan TDS dan TDD pada anak dan remaja, tetapi setelah dilakukan analisis multivariat didapatkan hasil bahwa hanya IMT dan LiPi yang paling berpengaruh pada kenaikan tekanan darah. ${ }^{23}$

Pada penelitian ini ditemukan hubungan signifikan antara LL dengan TDS dan TDD baik pada remaja laki - laki, perempuan, maupun kedua jenis kelamin $(p<0,05)$. Setelah dilakukan analisis multivariat didapatkan hasil bahwa LL merupakan indikator yang paling mempengaruhi TDS dan TDD pada remaja perempuan $(p, 0.0001)$. Hasil ini sesuai dengan penelitian hasil penelitian Preis et al yang menyatakan bahwa ada hubungan yang signifikan antara LL dengan TDS dan TDD ( $p<$ 0.0001). Berdasarkan hasil uji multivariat, LL tetap mempunyai hubungan yang signifikan dengan hipertensi walaupun sudah dikontrol dengan viceral adipose tissue (VAT) atau IMT dan LiPi. ${ }^{7}$

Banyak penelitian epidemiologi telah menunjukkan terjadinya peningkatan progresif peningkatan tekanan darah atau hipertensi dengan meningkatnya kejadian obesitas. ${ }^{6}$ Pada penderita obesitas akan lebih mudah terkena hipertensi, dan sebagian besar penderita hipertensi juga mengalami obesitas. $^{26}$ Pada Obesitas terjadi abnormalitas mekanisme kontrol tekanan arterial yang dapat meningkatkan tekanan darah, ekskresi natrium dan air melalui tekanan natriuresis dan diuresis. Selama ekskresi natrium dan air masih melebihi intake, akan terjadi peningkatan reabsorpsi pada tubular ginjal sehingga terjadi penurunan volume cairan ekstraseluler dan cardiac output sampai tekanan darah kembali nomal. Sebaliknya, ketika tekanan darah menurun, ginjal akan menahan garam dan air sampai tekanan arterial kembali normal. Tekanan natriuresis merupakan kunci utama feedback system yang menstabilkan tekanan darah dan volume cairan tubuh. ${ }^{5,26}$ Selain itu beberapa mekanisme lain juga dapat menjelaskan hipertensi pada obesitas antara lain aktivasi Sympathetic Nervous System (SNS), Rennin - Angiotensin System (RAS), glukokortikoid jaringan lemak, perubahan struktur ginjal, resistensi insulin, hiperleptinemia, dan vascular endothelial dysfuction.

Terapi non farmakologis dapat diberikan pada remaja yang mengalami hipertensi tahap awal, diantaranya menurunkan berat badan, meningkatkan aktivitas dan olah raga, mengurangi konsumsi makanan tinggi natrium, serta manajemen stres. Penerapan DASH (Dietary Approaches to Stop Hypertension) juga dapat memberikan efek yang signifikan terhadap penurunan tekanan darah. Diet DASH meliputi memperbanyak konsumsi sayur, buah, kacang kacangan, gandum utuh, susu, produk susu rendah lemak, ikan, unggas, dan mengurangi konsumsi makanan yang mengndung lemak jenuh dan gula. ${ }^{27}$

\section{SIMPULAN}

Prevalensi hipertensi pada remaja sebesar 14,7\%. Prevalensi obesitas berdasarkan IMT/U sebesar 14,7\%, LiPi sebesar 23,5\%, RLPTB sebesar $47,1 \%$, dan LL sebesar 29,5\%. Semua indikator status gizi mempunyai hubungan signifikan dengan tekanan darah. IMT merupakan indikator yang paling berhubungan dengan TDS dan TDD pada kedua jenis kelamin. Pada remaja laki - laki indikator yang paling berhubungan dengan TDS adalah IMT, dan TDD adalah LiPi. Pada remaja perempuan indikator yang paling berhubungan dengan TDS dan TDD adalah LL. 


\section{SARAN}

Untuk mencegah terjadinya hipertensi pada remaja perlu menurunkan berat badan, meningkatkan aktivitas dan olah raga apabila mengalami obesitas. Selain itu, remaja perlu menerapkan diet DASH meliputi memperbanyak konsumsi sayur, buah, kacang - kacangan, gandum utuh, susu, produk susu rendah lemak, ikan, unggas, dan mengurangi konsumsi makanan yang mengandung lemak jenuh dan gula

\section{DAFTAR PUSTAKA}

1. Theodore A, Kotchen JM. Nutrition, Diet, and Hypertension. In : Shils ME. Modern Nutrition In Health and Disease tenth edition. Philadelphia: Lippincott Williams and Wilkins; 2006.p.1095 102

2. Badan Penelitian dan Pengembangan Kesehatan. Riset Kesehatan Daerah (RISKESDAS) 2007. Departemen Kesehatan Republik Indonesia; 2008. Available from URL: HYPERLINK http//www.litbang.depkes.go.id/bl_riskesdas2007

3. Portman RJ, McNiece KL, Swinford RD, Braun Mc, Samuel JA. Pediatric hypertension: Diagnosis, Evaluation, Management, and Treatment for Primary Care Physician. Curr Probl Pediatr Adolesc health Care. 2005; 35: $262-94$

4. Syarif DR. Childhood Obesity: Evaluation and management, dalam naskah lengkap National Obesity Symposium II, editor: Adi S, dkk. Surabaya. 2003; 123 - 39

5. Kotsis V, Stabouli S, Papakatsika S, Rozos Z, Parati G. Mechanisms of Obesity-Induced Hypertension. Hypertension Research. 2010; 33: $386-93$

6. Zhou Z, Hu D, Chen J. Association between obesity indices and blood pressure or hypertension: which index is the best?. Public Health Nutrition. . 2008; 12(8): 1061 - 71

7. Preis SR, et al. Neck Circumference as a Novel Measure of Cardiometabolic Risk: The Framingham Heart Study. J Clin Endocrinol Metab. 2010; 95: 3701-10

8. Moore WE, Stephens A, Wilson T, Wilson W, Eichner JE. Body Mass Index and Blood Pressure Screening in a Rural Public School System: The Healthy Kid Project. Prev Chronic Dis. 2006; 3(4): $1-10$

9. Plachta-Danielzik S, Landsberg B, Johannsen M, Lange D, and Muller MJ. Association of Different Obesity Indices with Blood Pressure and Blood Lipids in Children and Adolescents. British Journal of Nutrition. 2008; 100: 208 - 18

10. Seidell JC, Perusse L, Despres JB, Bouchard C. Waist and hip Cicumference Have Independent and opposite effect on Cardiovascular Disease
Risk Faktor: The Quebec Family Study. Am J Clin Nutr. 2001; 74(3): 315 - 21

11. Hsieh SD, Yoshinaga H, Muto T. Waist-toHeight Ratio, A Simple and Practical Index for Assessing Central Fat Distribution and Metablik Risk in Japanesse Men and Women. Int J Relat Metab Disord. 2003; 27(5): 610 - 6

12. Hashemipour $\mathrm{M}$, et al. Association of Anthropometric Indexes and Cardiometabolic Risk Factors Among Obese Children. ARYA Atherosclerosis Journal. 2009; 5(1): 39 - 48

13. Ben-Noun LL, A Laor. Relationship Between Changes in Neck Circumference and Cardiovascular Risk Factors. Exp Clin Cardiol. 2006; 11(1): $14-20$

14. Badan Penelitian dan Pengembangan Kesehatan. Laporan Riset Kesehatan Dasar (RISKESDAS) Provinsi Bengkulu 2007. Departemen Kesehatan Republik Indonesia; 2008

15. National High Blood Pressure Education Program Working Group on High Blood Pressure in Children and Adolescenents. The Fourth Report on the Diagnosis, Evaluation and Treatment of High Blood Pressure in Children and Adolescenents. Pediatrics. 2004; 114: $555-$ 76

16. World Health Organization (WHO). Growth Tabel BMI for Age Boys and Girls. Availabe from URL: HYPERLINK: www.who.int/growthref/who2007_bmi_for_age/ en/index.html

17. Wang J, et al. Comparisons of Waist Circumferences Measured at 4 Sites. Am J Clin Nutr. 2003; 77: $379-84$

18. Rita YT. Sung, et al. Waist Circumference and Waist-to-Height Ratio of Hong Kong Chinese Children. BMC Public Health 2008; 8: 324

19. Nafiu OO, et al. Neck Circumference as a Screening Measure for Identifying Children With High Body Mass Index. Pediatrics 2010; 126: $306-10$

20. Luma GB, Spiotta RT. Hypertension in Children and Adolescents. American Family Physician. 2006; 73(9): $1558-66$

21. Diestiana H. Asupan Natrium Sebagai Faktor Risiko Hipertensi pada Anak Sekolah Dasar. KTI. Semarang: Program Studi Ilmu Gizi Fakultas Kedokeran Universitas Diponegoro; 2009

22. Salam MA. Risiko Faktor Hereditas, Obesitas, dan Asupan Natrium Terhadap Kejadian Hipertensi pada Remaja Awal. KTI. Semarang: Program Studi Ilmu Gizi Fakultas Kedokeran Universitas Diponegoro; 2009

23. Kelishadi R, et al. Association of Anthropometric Indices with Cardiovascular Diasease Risk Factor Among Children and Adolescent: CASPIAN Study. Int J Cardiol. 2007; 117(3): 340 - 8 
24. Cao Zhong-qiang, Zhu L, Zhang T, Wu L, Wang Y. Blood Pressure and Obesity Among Adolescents: A School-Based Population Study in China. American Journal of Hypertension. 2012; 25(5): $576-82$

25. Choy CS, Chan WY, Chen TL, Shih CC, Wu LC, Liao CC. Waist Circumference and Risk of Elevated Blood Pressure in Children: A Crosssectional Study. BMC Public Health. 2011; 11: 613

26. Tiengo A, Avogaro A. Cardiovasculer Disease. In: Bjorntorp Per, editor. Internatinal Textbook of Obesity. UK: John Wiley \& Sons Ltd. 2001; 365 $-77$

27. Irene Alton. Hypertension. In: Stang J, Story M, editor. Guideline for Adolescent Nutrition Service. Minneaapolis: University of Minnesota; 2005.p. $125-35$ 